\title{
Brand Name, Sales Promotion and Consumers' Online Purchase Intention for Cell-phone Brands
}

\author{
Mohammad Faryabi ${ }^{1}$, Kousar Sadeghzadeh Fesaghandis $^{1} \&$ Mortaza Saed $^{1}$ \\ ${ }^{1}$ Faculty of Economics Management and Business, University of Tabriz, Tabriz, Iran \\ Correspondence: Kousar Sadeghzadeh, Faculty of Economics Management and Business, University of Tabriz, \\ 29 Bahman Blvd., Tabriz, Iran. Tel: 98-939-249-5012. E-mail: kousarsadeghzadeh@gmail.com
}

Received: October 21, 2014

Accepted: December 7, 2014 Online Published: January 26, 2015

doi:10.5539/ijms.v7n1p167

URL: http://dx.doi.org/10.5539/ijms.v7n1p167

\begin{abstract}
Although "Internet" has become a wide channel for commercial transactions, yet most people have different concerns in trading through this media, especially within developing countries. This research seeks to examine the final impact of brand name and sales promotion, as two powerful marketing strategies, on consumers' online purchase intention, considering perceived quality, perceived value and store image as possible mediating variables affecting the decision making of consumers. For this purpose, two cell-phone brands (a well-known vs. to a less-known brand) were studied among 248 professors, employees and students from University of Tabriz, in IRAN. The required data was gathered by questionnaire and analyzed using SPSS and AMOS GRAPHICS soft-wares. The results indicate that online cell-phone stores in IRAN should respectively consider the importance of (1) strengthening their online store's image, (2) managing advertisements and increasing public awareness toward their brand, (3) upgrading service quality and (4) providing effective promotions to attract consumers over time.
\end{abstract}

Keywords: brand name, perceived quality, perceived value, promotion, purchase intention, store image

\section{Introduction}

Rapid changes of today's world have encountered organizations with different challenges. Meanwhile, only those organizations which useeffective management tools and technologies to take advantage of emerged opportunities are successful. Internet, as one of these tools, has become a wide channel for commercial transactions and a powerful media for organizations' marketing efforts. Statistical reports show a daily increase in the number of internet users and their growing tendency to trade via the internet. However, due to the novelty of this media and the relatively low knowledge toward it within developing countries, yet most people have different concerns in trading via the internet.

Creating a strong brand image can be a powerful marketing strategy to reducing the uncertainty inevaluating a product and increasing the online shoppers' purchase intention. Park and Stoel (2005) believe that because of the inability to examine a product physically in the online shopping context, consumers are likely to use recognizable cues (e.g., well-known brand names) to evaluate the value of a product, judge store image and make a purchase decision. Porter and Claycomb (1997) state that "a well-known familiar brand name associated with a positive brand image, creates competitive advantages in terms of increasing consumers' interest, attention and positive evaluation of a product, and encourages repeat purchases". When consumers lack knowledge about attributes of a product and are uncertain about the product, brand names play an important role in reducing perceived risk and assessing product quality (Dean, 1999). Therefore, creating an immensely popular and familiar brand is a competitive marketing strategy for online retailers.

Another way to attract more consumers and to enhance the competitiveness of online retailers is to offer promotions. According to Strahilevitz and Myers (1998) "an unexpected promotion may be attributed to pure luck and may reduce feelings of guilt associated with purchase of a product". In this regard, online retailers offer diverse and effective promotions (for example free shipping and discounts) (Oliver \& Shor, 2003). Promotions can facilitate consumers' purchase behaviors and satisfaction with purchases (Darke \& Dahl, 2003).

This research seeks to examine the final impact of brand name and promotion on consumers' purchase intention in online shopping context, considering perceived quality, perceived value and store image as mediating 
variables of the study. The study is sought to help organizations in developing effective marketing plans to make their brand more popular, throughe-business.The research isone of the few which investigate the impact of cell-phone brands and provided promotions for cell-phones, on consumers' online purchase intention in the studied country; Iran.

\section{Literature Review}

\subsection{Stimulus-Organism-Response (SOR) Paradigm}

The theoretical framework of this research is based on the stimulus-organism-response paradigm developed by Mehrabian and Russell (1974). The SOR paradigm explains how physical environments influence individuals' internal and behavioral states. The stimulus refers to attributes (e.g., product features, brand reputation, promotion, or price) that are located in the environment and influence individuals' affective and cognitive states (Park \& Lennon, 2009). The individuals' affective and cognitive states affected by stimuli finally result in their behavioral responses (e.g., approach or avoid behaviors) (Baker, Parasuraman, Grewal, \& Voss, 2002; Eroglu, Machleit, \& Davis, 2001, 2003). According to the environmental psychology research stream developed by Mehrabian and Russell (1974), atmospheric cues generate pleasure and arousal and in turn, lead to an approach/avoidance behavior. Most marketing scholars studying retail atmospherics follow Mehrabian and Russell's pleasure/arousal research tradition in which mood is a mediating factor between environmental cues and behavior.

\subsection{Stimulus: Brand Name and Promotion}

This study considers brand name and promotion as stimuli that activate consumers' affective and cognitive processes. A well-known familiar brand name associated with a positive brand image creates competitive advantages in terms of increasing consumers' interest, attention, and positive evaluation of a product (Porter \& Claycomb, 1997). Compared to unfamiliar brands, well-known brands have a potential to provide consumers with more information created by advertising, word-of-mouth communication, and previous purchases or usage of the brand (Stokes, 1985). Consumers tend to allocate more attention to a familiar brand and to engage more effort in processing information about a product with a well-known brand name (Shen, 2001). When consumers lack knowledge about attributes of a product and are uncertain about the product, brand names play an important role in reducing perceived risk and assessing product quality (Dean, 1999).

Promotions are another useful cue used for cognitive evaluations of a product and purchasing decisions (Raghubir, 2004). The American Marketing Association (AMA) defines a company's total promotion mix as the specific blend of advertising, sales promotion, public relations, personal selling and direct marketing tools that a company uses to persuasively communicate customer value and build customer relationships (Ehrman, 2011). Kotler (1999) defined sales promotions as "short-term incentives used to encourage the purchase or sale of a product or service". According to Kotler (1999) sales promotion includes a wide variety of promotion tools designed to stimulate earlier or stronger market response. Online retailers provide diverse sales promotions, such as free gifts, discounts, or free shipping to attract shoppers to their websites. Promotion is also one of the important attributes that contribute to generating positive store image (Collins-Dodd \& Lindley, 2003; Thang \& Tan, 2003). This study focuses on price discounts, as a type of sales promotion.

\subsection{Organism (Cognitive States): Perceived quality, Perceived Value, Store Image}

Cognitive states are defined as "the internal mental states of individuals" (Eroglu et al., 2001). The cognitive states investigated in this study were perceptions of product quality, product value and store image.

Perceived quality is defined as "a consumer's evaluation of a brand's overall excellence based on intrinsic (e.g., performance) and extrinsic cues (e.g., brand name)" (Kirmani \& Baumgartner, 2000). Brand name is a commonly used extrinsic cue to infer and/or maintain quality perceptions and can represent an aggregate of information about a product (Richardson, Dick, \& Jain, 1994). According to Della-Bitta, Monroe, and McGinnis (1981) "a strong brand name helps to control or stabilize the quality perceptions of a branded product even when its price is discounted". In addition, in a more recent study, Dodds, Monroe, and Grewal (1991) also found empirical support for the positive effect of brand name on quality perceptions.

Researchers have posited that value is an evaluation that balances what consumers receive in an exchange versus what they give up (e.g., Dodds et al., 1991). Thus, Perceived value is defined as "perceived net gains associated with a product/service that is influenced by a cognitive trade-off between perceived quality and perceived sacrifice" (Dodds et al., 1991). Previous research found a mediating effect of brand name on perceived value through perceived quality (Dodds et al., 1991; Grewal, Krishnan, Baker, \& Borin, 1998). 
Martineau (1958) introduced the concept of store image and defined it as "the way in which the shopper's mind pictures the store, partly by its functional qualities and partly by its atmosphere of psychological attributes". James, Durand, and Dreves (1976) on the other hand, defined store image as "a set of attitudes based upon evaluation of those store attributes deemed important by consumers". Grewal et al. (1998) mentioned that a store's consuming environment, service level and product quality are so-called store image.

\subsection{Responses: Purchase Intention}

Purchase intention represents the possibility that consumers will plan or be willing to purchase a certain product or service in the future. An increase in purchase intention means an increase in the possibility of purchasing (Dodds et al., 1991; Shiffman \& Kanuk, 2007). Researchers can use purchase intention as an important indicator for estimating consumer behavior. When consumers have a positive purchase intention, this forms a positive brand commitment which propels them to take an actual purchase intention (Shiffman \& Kanuk, 2007).

According to the SOR paradigm, consumer responses refer to approach or avoidance behaviors, which are consequences of affective and cognitive states (Eroglu et al., 2001). Approach behaviors include positive responses such as purchase intentions and patronage intentions (Eroglu et al., 2003). Behavioral intention may be a function of store image and perceived value. Positively evaluated store image and perceived value enhance customers' willingness to purchase a product, patronage intention, and loyalty (Bloemer \& Ruyter, 1998; Hsu \& Liu, 1998; Kim, 2004).

\section{Research Model and Hypotheses}

The model of this study (Figure 1) addresses how brand and promotion influence consumers' internal states and behavioral responses in the online cell-phone shopping context. The sequence of effects in the model is that brand and promotion (Stimulus) influence consumers' perceptions of product quality,product value and store image (Organism), eventually influencing consumers' purchase intention (Response). Based on this rationale and the SOR model, the following hypotheses are developed:

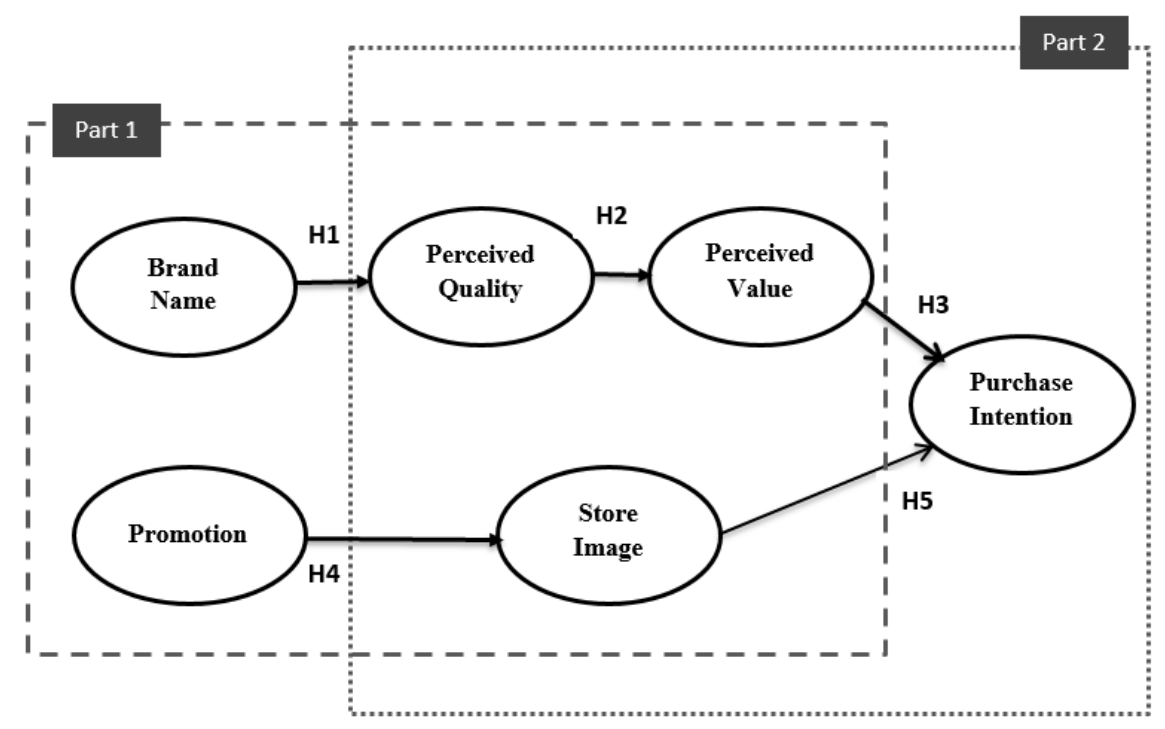

Figure 1. Proposed model for the study

H1. Brand name will be positively related to consumers' perceived quality.

H2. Perceived quality will be positively related to consumers' perceived value.

H3. Perceived value will be positively related to consumers' purchase intention.

H4. Promotion will be positively related to store image.

H5. Store image will be positively related to consumer's purchase intention. 


\section{Methods}

\subsection{Research Design}

To compare preference for a well-knownbrand vs. aless-known brand when price discounts are offered for them both, the authors used an online mock retail storeselling a variety of products (including cell-phones). The presented promotion code ("DISCOUNT") on the brand's image implied that the products of that brand are being offered with a $20 \%$ discount from their original price (equal to US \$190). Accordingly, the questionnaires were also divided into two categories based on two different experimental conditions (i.e., promotion code/well-known brand, vs. promotion code/less-known brand). Respondents were then asked to identify which brand they know better and are willing to buy if it is offered with a discount, and how other mediating variables affect this decision.

\subsection{Brand Selection}

As a well-known brand, Nokia is selected for this study. The reason for this selection is because Nokia is a long-established brand within the studied country; Iran. Also according to previous research, Nokia allocated first place in Iran's cell-phone market by year 2011 ("Tebyan-zn" website, 2012). Also as a less-known brand, HTC is selected because compared to Nokia, HTC is a new-comer brand within the studied country.

The authors selected two real brands (vs. to a real, and a mock brand) to increase the reliability of the results. According to what authors believe, in case a mock brand was invented as the study's less-known brand, a number of consumers would have selected the familiar brand (due to knowing it for a long time and showing bias) and this could affect the reliability of the results while in this study, though HTC is a new-comer brand, but it is familiar to a number of respondents and it is likely that not all respondents will choose Nokia.

\subsection{Sampling}

Cochran's formula was used to determine an appropriate sample size that would ensure the accuracy of the study findings. Accordingly, the study was conducted among 248 professors, employees and university students from University of Tabriz, in Tabriz, Iran, during April-June 2012. The reason for this choice was mainlythe respondents' ease of access and high probability of cooperation in the research process. Respondents were randomly selected, being asked whether or not they are willing to participate in the survey.

\subsection{Data Collection and Measures}

To answer the research questions and reach the study objectives, a total of 34 items areused with a five-point Likertscale (from $1=$ strongly disagree to $5=$ strongly agree). Items were all gathered from previousresearches (Appendix A).

Cronbach's $\alpha$ coefficient was used in this study to measure the internal consistency of the questionnaire and the results (Table 1) indicate an acceptable stability for the research questionnaire.

Table 1 . The reliability of studied variables

\begin{tabular}{lllllllll}
\hline & & BN & PD & PQ & PV & SI & PI & TOTAL \\
\hline \multicolumn{2}{l}{ Number of questions } & 6 & 3 & 9 & 4 & 6 & 6 & 34 \\
Cronbach's $\alpha$ & Nokia & .856 & .931 & .879 & .761 & .879 & .868 & .944 \\
& HTC & .952 & .950 & .954 & .871 & .875 & .923 & .984 \\
& Nokia \& HTC & .893 & .934 & .914 & .796 & .875 & .887 & .962 \\
\hline
\end{tabular}

Notes: $\mathrm{BN}=$ Brand Name, $\mathrm{PD}=$ Price Discount, $\mathrm{PQ}=$ Perceived Quality, $\mathrm{PV}=$ Perceived Value

$\mathrm{SI}=$ Store Image, $\mathrm{PI}=$ Purchase Intention

\section{Results}

\subsection{Sample Description}

The majority of the sample was female (53.2 percent), and 51.1 percent of the respondents were in the age range of 21-25, being bachelor students (66.5 percent) (Appendix B). It is worth to note that 71.8 percent of respondents mentioned that they are more familiar with the Nokia brand, while answering the questionnaire, while only 28.2 percent mentioned HTC as a brand they are familiar with. This shows that the majority of the sample knows Nokia as a long-established, well-known brand and could be in-turn, considered as proof for the preciseness of the selected brands in the study. 


\subsection{Manipulation Checks}

Participants evaluated brand familiarity (well-known/less-known) to check the brand manipulation. Results of $\mathrm{t}$-tests revealed significant differences between Nokia $(\mathrm{M}=3.94, \mathrm{t}=20.33)$ and $\mathrm{HTC}(\mathrm{M}=3.85, \mathrm{t}=8.939)$.

\subsection{Univariate Analysis}

According tothe Univariate analysis (Table 2), variables' means earned an above-average score considering the measurement scale (5-point Likert scale); thus, each had an appropriate position in the studied sample.

The Skewness and Kurtosis statistic results also showed the isotropy of the obtained answers. In general, if the absolute value of Skewness and kurtosis coefficients is smaller than one, then it is said that the distribution is almost normal. For this study, most variables' Skewness and Kurtosis coefficient had little difference with normal distribution. Furthermore, all variables had negative Skewness, presenting the responses' focus on above-average. We also used one sample t-test to examine the studied variables' status among the sample and considered 3 as the test value. Based on this, hypothesis zero for each variable meant that the variable's status was equal with 3 . Obtained results did not confirm hypothesis zero for any of the variables, also given borders were all positive, showing the appropriate status of all studied variables within the sample.

Table 2. Descriptive statistics of variables

\begin{tabular}{lllllll}
\hline & & Mean & Std. deviation & Skewness & Kurtosis & t-test \\
\hline BN & Nokia & 3.94 & .66 & -.455 & .219 & 20.337 \\
& HTC & 3.85 & .85 & -.831 & .639 & 8.932 \\
& Nokia \& HTC & 3.91 & .72 & -.673 & .702 & 21.445 \\
PD & Nokia & 3.35 & .95 & -.159 & -.427 & 5.310 \\
& HTC & 3.43 & 1.04 & -.673 & -.160 & 3.699 \\
& Nokia \& HTC & 3.37 & .98 & -.320 & -.375 & 21.445 \\
PQ & Nokia & 4 & .50 & -.543 & 2.282 & 28.178 \\
& HTC & 3.83 & .75 & -.630 & .602 & 9.932 \\
& Nokia \& HTC & 3.95 & .59 & -.756 & 1.986 & 27.246 \\
PV & Nokia & 3.60 & .69 & -.170 & -.062 & 12.543 \\
& HTC & 3.80 & .74 & -.651 & .405 & 9.651 \\
& Nokia \& HTC & 3.66 & .71 & -.292 & -.045 & 15.705 \\
SI & Nokia & 3.53 & .70 & -.123 & .040 & 10.839 \\
& HTC & 3.67 & .70 & -.327 & -.038 & 8.647 \\
& Nokia \& HTC & 3.57 & .70 & -.177 & -.034 & 13.739 \\
PI & Nokia & 3.58 & .68 & -.116 & -.431 & 12.257 \\
& HTC & 3.72 & .80 & -.598 & .225 & 8.017 \\
& Nokia \& HTC & 3.62 & .72 & -.259 & -.216 & 14.600 \\
\hline
\end{tabular}

\subsection{Spearman Correlation between Variables}

A correlation analysis was done to determine the strength and direction of the relationships between each two dependent and independent variable, using spearman's correlation test and considering the multi-valued rating of the measurement scale (Table 3). The results presented a high amount of effectiveness amongstudied variables. According to obtained coefficients, the relations between the variables were confirmed at the significant level of 1 percent. 
Table 3. Spearman correlation between variables

\begin{tabular}{llll} 
& & Spearman & Sig. \\
BN \& PQ & Nokia & $.488^{*}$ & .000 \\
& HTC & $.938^{*}$ & .000 \\
& Nokia \& HTC & $.637^{*}$ & .000 \\
& Nokia & $.284^{*}$ & .000 \\
& HTC \& PV & $.945^{*}$ & .000 \\
& Nokia \& HTC & $.471^{*}$ & .000 \\
& Nokia & $.897^{*}$ & .000 \\
& HTC $\&$ SI & $.943^{*}$ & .000 \\
& Nokia \& HTC & $.910^{*}$ & .000 \\
& Nokia & $.859^{*}$ & .000 \\
& HTC & $.891^{*}$ & .000 \\
& Nokia \& HTC & $.871^{*}$ & .000 \\
& Nokia & $.799^{*}$ & .000 \\
& HTC & $.831^{*}$ & .000 \\
& Nokia \& HTC & $.810^{*}$ & .000 \\
\hline
\end{tabular}

Note. ${ }^{*} \mathrm{p}<0.05$

\subsection{Hypotheses Testing}

The study model examined the relation betweenthe variables using Amos Graphics and structural equation modeling (SEM). According to the SEM results, all path coefficients were significant at the $\mathrm{P}<0.05$ level. Therefore, all studied hypotheses were confirmed (Table 4). The results of goodness of fit for the model were also satisfactory (Table 5).

Table 4. Hypotheses test results

\begin{tabular}{llllll}
\hline Path & & & & \\
\cline { 1 - 2 } From & To & & Path coefficient & t-value & P \\
\hline BN & PQ & Nokia & .88 & 6.39 & .000 \\
& & HTC & 1.43 & 10.52 & .000 \\
& & Nokia \& HTC & 1.11 & 10.06 & .000 \\
PQ & PV & Nokia & 1.13 & 6.53 & .000 \\
& & HTC & .92 & 25.63 & .000 \\
& & Nokia \& HTC & .98 & 10.98 & .000 \\
PV & PI & Nokia & .51 & 4.02 & .000 \\
& & HTC & .52 & 6.85 & .000 \\
& & Nokia \& HTC & .83 & 7.62 & .000 \\
PD & SI & Nokia & .40 & 8.76 & .000 \\
& & HTC & .62 & 7.74 & .000 \\
& & Nokia \& HTC & .46 & 11.01 & .000 \\
SI & PI & Nokia & 2.08 & 7.78 & .000 \\
& & HTC & .93 & 5.68 & .000 \\
& & Nokia \& HTC & 1.54 & 9.30 & .000 \\
\hline
\end{tabular}

Table 5. Model fit indicators

\begin{tabular}{lllll}
\hline Indicator & Indicator type & $\begin{array}{l}\text { Accepted amount for an optimal } \\
\text { model fit }\end{array}$ & $\begin{array}{l}\text { Amount in Research } \\
\text { model }\end{array}$ & Result \\
\hline RMSEA & Absolute & Lower than .08 & .067 & Acceptable \\
IFI & Comparative & Higher than .9 & .919 & Acceptable \\
CFI & Comparative & Higher than .9 & .918 & Acceptable \\
PCFI & Parsimony & Higher than .6 & .799 & Acceptable \\
PNFI & Parsimony & Higher than .6 & .752 & Acceptable \\
CMIN/DF & Parsimony & Between $2 \& 3$ & 2.281 & Acceptable \\
HOELTER & Sample Size Adequacy & 138 & 284 & Acceptable \\
\hline
\end{tabular}




\section{Discussion and Conclusions}

The study examined the final effect of brand name and promotion on consumers' perceptions of product quality, value and store image and eventually consumers' purchase intention in online cell-phone shopping context. For this purpose and based on the existing literature, several hypotheses were proposed and tested in the study, using structural equation modeling.

Suhr (2008) states that standardized path coefficients with a value less than 10 percent show a low impact, standardized path coefficients witha value around 30 percent show a medium, and standardized path coefficients with a value more than 50 percentshow a high impact of the independent variable on the dependent variable in hypotheses. Accordingly, in this study, except of promotion that had a medium impact on store image (46 percent), other variables, all hada high impact on their dependent variable in each hypothesis. Also goodness of fit test results showed that the research model could largely be acceptable and is a good fit.

\subsection{The Joint Evaluation of Hypothesis Test Results forthe Studied Brands}

The results of joint evaluation of hypothesis testing for Nokia and HTC brands show that among all tested hypothesis, the effect of store image on consumer's purchase intention had the highest path coefficient value. This result has important implications for online sales managers alike: consumers' intention in purchasing a product can be influenced by the online store which the product is sold and consumers may derive some amount of "added value" from the image of the store (e.g., "I bought this cell-phone from a more prestigious store so it has better value"). Accordingly, manufacturers should be careful in choosing those retailers whose image is consistent with their brand's positioning.

The results also showed that in general, brand name had a high impact on perceived quality of the brand, meaning that a popular and well-known name has positive impact on consumers' perceptions of the quality of the productsassociated with the brand. Consumers consider that products of a well-known brand are likely to have high quality. Thus, producersmust increase the social awareness toward their brandand make a proper position for it among the target populationby using appropriate advertising methods.

Meanwhile, perceived quality had a high impact on perceived value of the brand. Mainly, while evaluating a product, customers balance the product's probable quality with its price and as Zeithaml (1988) concludedwhen the perceived quality of a brand is high, it affects the perceived value of the brand, positively.

Hypothesis test results also show the high impact of perceived value on purchase intention. When the perceived value of a specific brand is high, or in other words, when the purchase of a brand seems affordable, this notion positively influences consumers'purchase intention and increases it.

The results finally showed the medium impact of promotion on store image. Accordingly, providing price discounts leads to attraction of customers to a specific store and purchasing from the store, in comparison to the time when no discount had been offered.

The obtained results of this research are consistent with the results of Della Bitta et al. (1981), Dodds et al. (1991), Grewal et al. (1998), Wu, Yeh, and Hsiao (2011) and etc. (Table 6).

Table 6. Comparison of previous research results with the current research

\begin{tabular}{llll}
\hline Researcher & Year & Summary of results & Consistency \\
\hline Della Bitta et al. & 1981 & Brand name has a positive effect on perceived quality & Consistent \\
Dodds et al. & 1991 & & \\
Yang & 2012 & & Consistent \\
Azad \& Safaei & 2012 & & Consistent \\
Dodds et al. & 1991 & Perceived quality has a positive effect on perceived value & Consistent \\
Grewal et al. & 1998 & Perceived value has a positive effect on purchase intention & \\
Tseng \& Tsai & 2011 & & Consistent \\
Buckley & 1991 & Store image has a positive effect on purchase intention & \\
Shih & 2010 & & \\
Wu et al. & 2011 & & \\
Thang \& Tan & 2003 & Promotion has a positive effect on store image & \\
\hline
\end{tabular}




\subsection{A Comparative Study of Hypothesis Test Results for the Studied Brands}

According to the obtained results, the impact that HTC brand name had on perceived quality was higher than the effect that Nokia had on perceived quality. It can be understood that although HTC is an almost newcomer brand in the studied society, it has succeeded to gain a growing credibility and attractiveness among its consumers, using appropriate advertising methods and increasing social awareness toward its product characteristics. Also the impact of perceived value on purchase intention was higher in HTC, showing that in general, consumers believe that what they overall acquire from HTC is worth the expenses. Furthermore, the impact of promotion on store image was also higher in HTC. Meanwhile, the perceived quality of Nokia brand had a higher impact on perceived value, in comparison to HTC. In fact, most consumers tend to believe that Nokia's products have better quality than HTC products. Finally, the impact of store image on purchase intention was higher in Nokia.

\section{Practical Suggestions}

Thecurrent study provides some practical suggestions for manufacturers and online sales managers of both well-known and less-known cell-phone brands.

\subsection{Customer Orientation: Key to Improving Store Image}

As stated in subsection 6.1, consumers' intention in purchasing a product can be influenced by the store which the product is sold. For example "I bought this cell-phone from a prestigious store, therefore, it has better value".Given this fact, manufacturers should be careful in choosing those retailers whose image is consistent with their brand's positioning, in terms of:

- Services: For example, online payment possibility, online response tothe probable questions of customers or even developing an online conversation system for information exchanges about products' technical deficiencies, among customers and staff or free home delivery that all can improve the image of an online store.

- Atmosphere: In addition to services, the elegant, sedative and user-friendly design of a store's website can also facilitate the evaluation of products and increase shoppers' purchase intentions. For example, choosing an appropriate background music or color combination for astore's website can affect customers' perceptions toward the store and encourage them to visit and purchase from it. Perhaps, a specific type of music would make customers to spend more time checking the online store or even stimulate them to make a purchase! Music can also affect customers' evaluation of their shopping experience. However, one must remember that different customers have different personalities, and thus, different preferences! Some type of customers would perhaps, close your website IMMEDIATELY after hearing the music, walking on their nerves...! So, you must not get frustrated with this. Rather, go beyond, and itemize different types of music on your store's website. Help customers stimulate themselves to purchase! Aha! Let customers feel your store friendly, and cool! More importantly, design a user-friendly payment system, so that customers do not get confused. In fact, some customers abandon purchasing a product online, only because they get lost between a website's wrapped pages, as we also do sometimes!

- Customer orientation: Given the fact that customers are the most important source of profitability of every company, we suggest companies to strengthening CRM system; managing the way to deal with customers' questions, requests and more importantly, managing customers' complaints about the purchased goods/ services. In general, developing a customer-oriented system that its first and last goal is to satisfy customers, leads to the improvement of astore's image. In this regard, the familiarity of the staff - especially those who are in direct relation with customers (either online or face-to-face) - with the essentials of Neuro-linguistic programming (NLP) would be a great help in communicating with customers and through, improving store image. The title; NLP, coined by Bandler and Grinder (1975), is understood to denote that a person is a whole mind-body system, with systematic, patterned connections between neurological processes ('neuro'), language ('linguistic') and learned behavioral strategies ('programming') (Dilts et al., 1980). NLP has been defined in various ways. In its promotional literature it is described as (for example) 'the art of communication excellence' (Tosey \& Mathison, 2006).

\subsection{ManageAdvertisements: Familiarizethe Public with Your Brand}

According to the obtained results, brand name had a high impact on perceived quality. Generally, most customers consider that a well-known brand has better quality in comparison to a product associated with an un-known or less-known brand. In this regard, to increase public awareness towarda specific brand, a company mustuse appropriate advertising methods. OK, you say "I KNOW THIS!" But what is really important is that retailers must ensure that there is consistency between the advertising messages and the products/services characteristics to strengthen the brand's image and increaseits reputation over time. This helps customers to trust 
the brand and be encouraged to purchasing it. In other words, we must provide customers, exactly what we promise and claim in our advertisements and advertisements similarly, must present the actual characteristics of what we provide, without any kind of exaggeration. This, leads to customers trust and increases purchase intention. A well-known brand, as Dodds et al. (1991) also conclude in their study, leads to customers' positive judgment of product quality and decreases the risk of purchasing. In other words, a prestigious brand is considered as the product quality' assurance from the manufacturer and reminds manufacturers, their obligation to provide what customers desire to receive.

\subsection{Increasing Perceived Quality}

Hypothesis test results showed the positive impact of perceived quality on perceived value. Accordingly:

- A specific brand's manufacturers, doing the necessary revisions in product design; (whether in terms of industrial-electronic orin terms of appearance adornment) must apply required accuracy to produce products that are economically affordable, technically user-friendly and in terms of design and appearance, satisfactory.

Increasing a brand's actual quality makes its products to be known as high quality productsin customers' minds over time and as Zeithaml (1988) and Grewal et al. (1998) conclude, perceived quality of a brand has positive impact on its perceived value. When customers believe that the probable quality of a specific brand is high, they imagine that the probability that its purchase would be a bargain is also high. In simple words, customers believe that what they are receiving is worth the cost.

\subsection{Provide Promotions, But Intelligently!}

According to the results, promotion had a positive impact on store image. In this regard:

- Although price discount hasa positive impact on store image, retailers have to use words such as "sale" or "special" on discounts, so customers believe that the discount is only temporary and do not consider it as a reason for the poor quality of the product or being fashioned. Customers, while examining a product to make purchase decision, tend to have assurance about the product quality and etc. Providing an unconscious promotion for a brand's products, leads to a type of defect in customers' minds about the products' characteristics. Customers might imagine "Discount for brand X!? This seemsmysterious! Maybe these products are faulty or fashioned".

- Word-of-mouth advertisements are also useful in success of a specific brand's promotional strategies and if managed appropriately, each customer will encourage others to visit a specific store and purchase a brand associated with discount.

\section{Future Research}

\subsection{Introducing a New Brand}

Introducing a new brand may be a critical issue because consumers do not have knowledge about the brand. When consumers evaluate a new brand without knowledge or experience, other environmental cues (e.g., product styles and attributes, layout, website design, services) may influence the perceived brand image. Further research can focus on examining which environmental cues affect perceived brand image when a new brand (vs. a well-known brand) is introduced.

\subsection{The Negative and Positive Effects of Promotions on Consumers' Purchase Intention}

Although the research found a positive impact of price discounts on consumers' responses, there is a need for understanding the negative effect of promotions on consumers' responses. For example, if a free gift is offered with purchase of a product, consumers may infer that the actual price of the product is likely to be inflated in order to cover the cost of the free gift.

In addition, consumers may not be interested in having free gifts or do not want to use them (Raghubir, 2004). Thus, an important issue is to investigate the positive and negative effect of different promotions in online shopping.

\subsection{The Effect of Different Promotions on Perceived Value}

Studying the effect of different promotions on perceived value would also be useful. For example, in a situation that a price discount is offered for a specific product, the perceived savings would be greater for consumers, in comparison to a time when there are no discounts offered. Furthermore, the increase of perceived value in turn, would possibly increase consumers' purchase intention. 


\subsection{Effect of Store Image on Purchase Intention for Services}

Moreover, the model tested in this paper could also be extended to other products or services. It could be argued that store image may be even more important in the purchase of a service because the service encounter takes place in the "store" and the service quality, the existing facilities in the store and the atmosphere (color, design, the existing music's rhythm or even more important, the employees' characteristics and behavior, appearance adornment, appropriate social behavior, negotiation skills and having patience), altogether may influence customers' behavior and increase their intention to visit a specific store and utilize its provided services.

\subsection{Word-of-Mouthand Consumers' Visit and Purchase Intentions}

Further research can also study the impact of word-of-mouth in increasing customer's intention to visit and purchase a specific product from a store. For example, when a discount is offered for a product, surprised customers would tell each other about the product and this would increase visits to the store and hopefully, sales could increase. Word-of-mouth would also have a great impact on consumers' perceptions toward a store, when they talk about the provided services in the store, the quality of services, store atmosphere, the way the store employees treat consumers, etc.).

\section{References}

Aaker, D. (1991). Managing Brand Equity: Capitalizing on the Value of Brand Name. NY: The Free Press.

Azad, N., \& Safaei, M. (2012). The Impact of Brand Value on Brand Selection: Case Study of Mobile Phone Selection, Management Science Letters, 2, 1233-1238. http://dx.doi.org/10.5267/j.msl.2012.02.014

Baker, J., Parasuraman, A., Grewal, D., \& Voss, G. B. (2002). The influence of Multiple Store Environment Cues on Perceived Merchandise Value and Patronage Intentions. Journal of Marketing, 66(2), 120-141. http://dx.doi.org/10.1509/jmkg.66.2.120.18470

Bloemer, T. J., \& Ruyter, K. D. (1998). On the Relationship between Store Image, Store Satisfaction and Store Loyalty. European Journal of Marketing, 32(5/6), 499-513.

Collins-Dodd, C., \& Lindley, T. (2003). Store Brand and Retail Differentiation: The Influence of Store Image and Store Brand Attitude on Store Own Brand Perceptions. Journal of Retailing and Consumer Services, 10(6), 345-352. http://dx.doi.org/10.1016/S0969-6989(02)00054-1

Darke, P. R., \& Dahl, D. W. (2003). Fairness and Discounts: the Subjective Value of a Bargain. Journal of Consumer Psychology, 13(3), 328-338.

Dean, D. H. (1999). Brand Endorsement, Popularity and Event Sponsorship as Advertising Cues Affecting Consumer Pre-purchase Attitudes. Journal of Advertising, 28(3), 1-12. http://dx.doi.org/10.1080/00913367.1999.10673585

Della-Bitta, A., Monroe, K. B., \& McGinnis, J. M. (1981). Consumer Perceptions of Comparative Price Advertisements. Journal of Marketing Research, 18(November), 416-427.

Dilts, R., Grinder, J., Bandler, R., \& DeLozier, J. (1980). Neuro-linguistic Programming: Volume 1, the study of the structure of subjective experience. CA: Meta Publications.

Dodds, W. B., Monroe, K. B., \& Grewal, D. (1991). Effects of Price, Brand and Store Information on Buyers' Product Evaluation. Journal of marketing research, 28(3), 307-319.

Ehrman, Ch. (2011). Toward Finding an Optimal Mix between Push and Pull Strategies: Try Conjoint Analysis. The Journal of American Academy of Business, 17(1), 196-201.

Eroglu, S. A., Machleit, K. A., \& Davis, L. M. (2001). Atmospheric Qualities of Online Retailing: A Conceptual Model of Implications. Journal of Business Research, 54, 177-184.

Eroglu, S. A., Machleit, K. A., \& Davis, L. M. (2003). Empirical Testing of a Model of Online Store Atmospherics and Shopper Responses. Psychology and Marketing, 20(2), 139-150.

Grewal, D., Krishnan, R., Baker, J., \& Borin, N. (1998). The Effect of Store Name, Brand Name and Price Discounts on Consumer's Evaluations and Purchase Intentions. Journal of Retailing, 74(3), 331-352. http://dx.doi.org/10.1016/S0022-4359(99)80099-2

Han, J. W., \& Kwon, H. H. (2009). The Mediating Effect of Perceived Quality between Extrinsic Cues and Perceived Value in Ski Products. International Journal of Sports Marketing \& Sponsorship, 287-301. 
Hanzaee, K. H., \& Taghipourian, M. J. (2012). The Effects of Brand Credibility and Prestige on Consumers Purchase Intention in Low and High Product Involvement. Journal of Basic and Applied Scientific Research, 2(2), 1281-1291.

Hsu, C., \& Liu, B. S. (1998). The Role of Mood in Price Promotions. Journal of Product \& Brand Management, $7(2), 150-60$.

James, D. L., Durand, R. M., \& Dreves, R. A. (1976). The Use of a Multi-attribute Model in a Store Image Study. Journal of Retailing, 52(2), 23-32.

Khasawneh, K., \& Hasouneh, A. B. (2010). The Effect of Familiar Brand Names on Consumer Behaviour: A Jordanian Perspective. International Research Journal of Finance and Economics, 43, 33-57.

Kim, M. (2004). Consumer Response to Stock Outs in Online Apparel Shopping (Unpublished doctoral dissertation). The Ohio State University, Columbus, $\mathrm{OH}$.

Kirmani, A., \& Baumgartner, H. (2000). Reference Points Used in Quality and Value Judgments. Marketing letters, 11(4), 299-310. http://dx.doi.org/10.1023/A:1008129011202

Kotler, P. (1994). Marketing Management: Analysis, Planning, Implementation and Control. Englewood Cliffs: Prentice Hall.

Kotler, P., \& Armstrong, G. (1996). Principles ofMarketing. New Delhi: Prentice-Hallof India.

Kotler, P., Armstrong, G., Saunders, J., \& Wong, V. (1999). Principles of Marketing (2nd European Edition). Europe: Prentice Hall Inc.

Martineau, P. (1958). The Personality of a Retail Store. Harvard business review, 36(1), 47-55.

Mehrabian, A., \& Russell, J. A. (1974). An Approach to Environmental Psychology. MA: MIT Press, Cambridge.

Oliver, R. L., \& Shor, M. (2003). Digital Redemption of Coupons: Satisfying and Dissatisfying Effects of Promotion Codes. Journal of Product \& Brand Management, 12(2), 121-134.

Park, J., \& Stoel, L. (2005). Effect of Brand Familiarity, Experience and Information on Online Apparel Purchase. International Journal of Retail \& Distribution Management, 33(2), 148-160. http://dx.doi.org/10.1108/13612020910957680

Park, M., \& Lennon, Sh. (2009). Brand name and Promotion in Online Shopping contexts. Journal of Fashion Marketing and Management, 13(2), 149-160.

Porter, S. S., \& Claycomb, C. (1997). The Influence of Brand Recognition on Retail Store Image. Journal of Product \& Brand Management, 6(6), 373-387.

Raghubir, P. (2004). Free Gift with Purchase: Promoting or Discounting the Brand? Journal of Consumer Psychology, 14(1/2), 181-186.

Richardson, P. S., Dick, A. S., \& Jain, A. K. (1994). Extrinsic and Intrinsic Cue Effects on Perceptions of Store Brand Quality. Journal of Marketing, 58(October), 28-30.

Schiffman, L. G., \& Kanuk, L. L. (2007). Consumer Behavior (9th ed.). NJ: Prentice-Hall Inc.

Shen, F. (2001). Effects of Violence and Brand Familiarity on Responses to Television Commercial. International Journal of Advertising, 20, 381-397.

Shih, T. Y. (2010). Comparative Analysis of Marketing Strategies for Manufacturers' and Retailers' Brands. International Journal of Electronic Business Management, 8(1), 56-67.

Stokes, R. (1985). The Effect of Price, Package Design, and Brand Familiarity on Perceived Quality. In J. Jacoby \& J. C.Olson (Eds.), Perceived Quality: How Consumers View Stores and Merchandise (pp. 233-246). Lexington, MA: Lexington Books.

Strahilevitz, M. A., \& Myers, J. G. (1998). Donations to Charity as Purchase Incentives: How Well They Work May Depend on What You Are Trying to Sell. Journal of Consumer Research, 24(4), 434-446.

Suhr, D. (2008). Step Your Way Through Path Analysis. Annual Conference Proceedings, Western Users of SAS Software. CA: Universal City.

Thang, D. C. L., \& Tan, B. L. B. (2003). Linking Consumer Perception to Preference of Retail Stores: An Empirical Assessment of the Multi-attributes of Store Image. Journal of Retailing and Consumer Services, 10(4), 193-200. http://dx.doi.org/10.1016/S0969-6989(02)00006-1 
The best sold cell-phones in Iran's market. (2012, April 16). In Tebyan-zn Website. Retrieved May 3, 2012, from http://www.tebyan-zn.ir/News Article/mobile_phone_electronics/news_mobile_tech/2012/4/16/58896.html

Tong, X., \& Hawley, J. M. (2009). Measuring Customer-based Brand Equity: Empirical Evidence from the Sportswear Market in China. Journal of Product \& Brand Management, 18(4), 262-271.

Tosey, P., \& Mathison, J. (2006). Introducing Neuro-Linguistic Programming. Centre for Management Learning $\&$ Development, School of Management, University of Surrey.

Wang, E. S. T. (2010). Impact of Multiple Perceived Value on Consumers' Brand Preference and Purchase Intention: A Case of Snack Foods. Journal of Food Products Marketing, 16(4), 386-397. http://dx.doi.org/10.1080/10454446.2010.509242

Wu, P. C., Yeh, G., \& Hsiao, C. R. (2011). The Effect of Store Image and Service Quality on Brand Image and Purchase Intention for Private Label Brands. Australasian Marketing Journal, 19(1), 30-39. http://dx.doi.org/10.1016/j.ausmj.2010.11.001

Yoo, B., Donthu, N., \& Lee, S. (2000). An Examination of Selected Marketing Mix Elements and Brand Equity, Journal of the Academy of Marketing Science, 28(2), 195-211.

Zeithaml, V. A. (1988). Consumer Perceptions of Price, Quality, and Value: A Means-end Model and Synthesis of Evidence. Journal of Marketing, 52, 2-22.

\section{Appendix A}

\section{The Survey Questions}

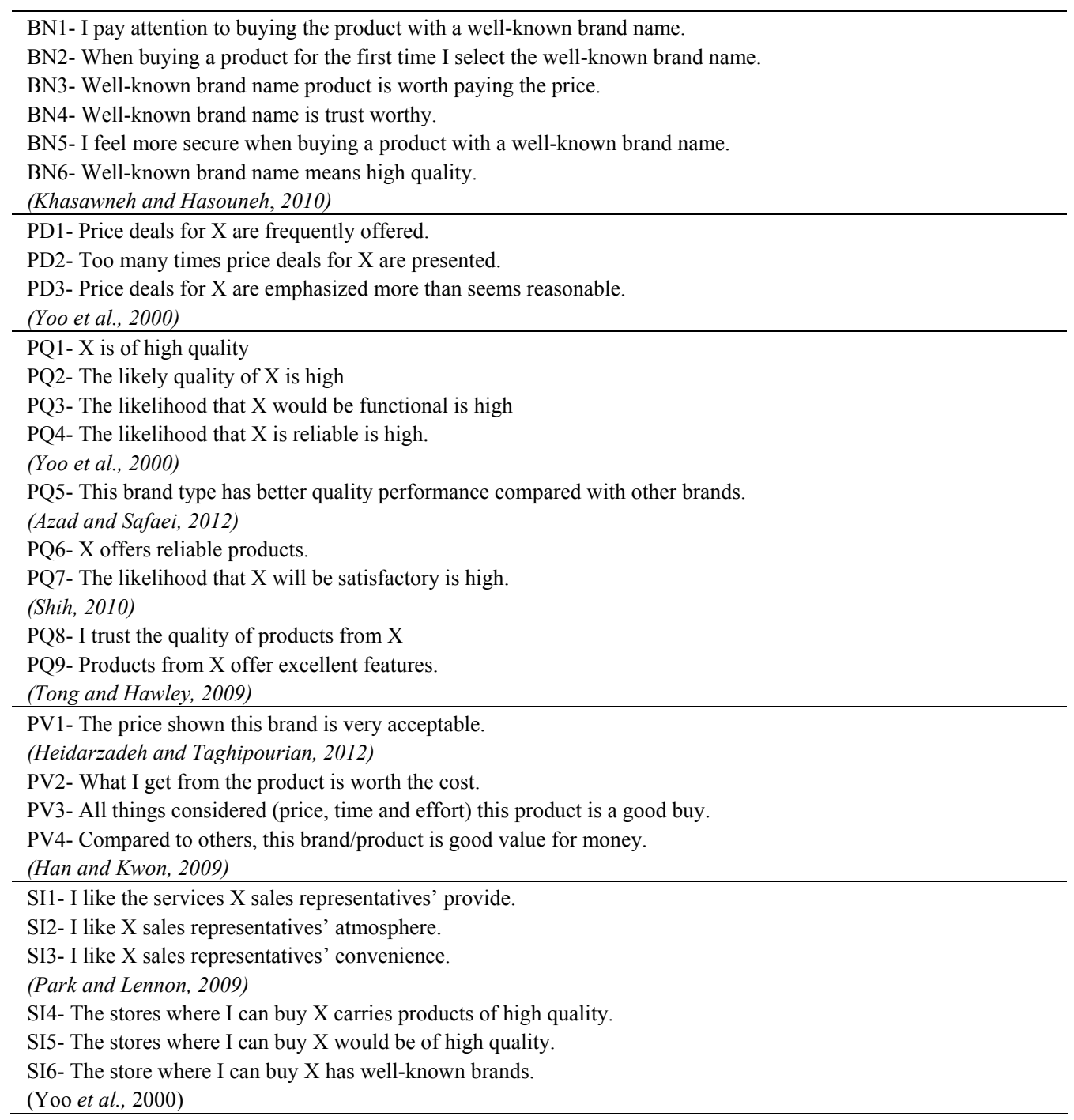


PI1- The likely that I will shop for this merchandise via this online store is high.

PI2- The likely that I will purchase this merchandise via this online store is high.

(Park and Lennon, 2009)

PI3- This brand is my preferred brand over other similar brands.

(Wang, 2010)

PI4- I am willing to pay money for brand X.

PI5- I consider buying brand X products If I need to buy something.

PI6- I recommend brand X products to other costumers.

(Shih, 2010)

Note. $\mathrm{BN}=$ Brand Name, $\mathrm{PD}=$ Price Discount, $\mathrm{PQ}=$ Perceived Quality, $\mathrm{PV}=$ Perceived Value

$\mathrm{SI}=$ Store Image, $\mathrm{PI}=$ Purchase Intention

\section{Appendix B}

\section{Respondents' General Characteristics}

\begin{tabular}{lll}
\hline & Frequency & Percent \\
\hline Gender & & \\
Male & 133 & 46.8 \\
Female & 151 & 53.2 \\
Age & & \\
$15-20$ & 33 & 11.6 \\
$21-25$ & 145 & 51.1 \\
$26-30$ & 36 & 12.7 \\
$31-35$ & 38 & 13.4 \\
$36-40$ & 12 & 4.2 \\
$41-45$ & 17 & 6 \\
$46-50$ & 3 & 1.1 \\
Education & & \\
Bachelor & 189 & 66.5 \\
Master & 65 & 22.9 \\
Phd & 30 & 10.6 \\
\hline
\end{tabular}

\section{Copyrights}

Copyright for this article is retained by the author(s), with first publication rights granted to the journal.

This is an open-access article distributed under the terms and conditions of the Creative Commons Attribution license (http://creativecommons.org/licenses/by/3.0/). 